\title{
A study of the water quality of the Mhlathuze River, KwaZulu-Natal (RSA): Microbial and physico-chemical factors
}

\author{
$\mathrm{J} \mathrm{Lin}^{1 *}$, PT Biyela ${ }^{2}$, T Puckree ${ }^{3}$ and CC Bezuidenhout ${ }^{4}$ \\ ${ }_{1}^{1}$ Department of Microbiology, University of Durban Westville, Private Bag X54001, Durban 4000, South Africa \\ ${ }^{2}$ Department of Biochemistry and Microbiology, University of Zululand, Private Bag X1001, KwaDlangezwa, 3886, South Africa \\ ${ }^{3}$ Department of Physiotherapy, University of Durban Westville, Private Bag X 54001, Durban, 4001, South Africa \\ ${ }^{4}$ School of Environmental Science and Development, University of Potchefstroom for CHE, Private Bag X6001, Potchefstroom 2520, \\ South Africa
}

\begin{abstract}
The microbial quality (total and faecal coliform counts) and some physico-chemical parameters of the Mhlathuze River water source were monitored during March 2001 to November 2002 and compared to the previous study conducted during 1998-1999. The results showed that most of the physical and chemical values obtained were within the recommended limits specified in the South African Water Quality Guidelines. High concentrations of metal were detected in water samples from Felixton and the Richards Bay estuary. Water samples from the Mhlathuze Pumping Station and Felixton, which contained higher concentrations of total nitrogen and phosphate, possessed higher faecal coliform contamination than other sites. The total coliform counts of the Mhlathuze River in this study period were noted to be significantly higher than those in the 1998 to 1999 period. As observed in the previous study, Felixton continues to be the site with major faecal contamination. The resuscitation results indicated that the level of faecal contamination in the Mhlathuze catchment was higher than that measured using conventional methods. Therefore the real impact of this "viable but non-culturable" state of micro-organisms in this water system requires urgent attention. Larger fluctuations in the trend of total and faecal coliform counts were observed in 2001. This phenomenon coincided with the major construction of the Mhlathuze pumping station. High water surface temperatures and rainfall figures might have also contributed to this observation. Evidence from our results strongly suggests that the use of faecal coliform bacteria as indicators should be expanded and more research is indicated to identify the impact of the "viable but non-culturable" (VBNC) state of pathogens in this environment.
\end{abstract}

Keywords: water quality, total and faecal coliforms, physico-chemical, Mhlathuze

\section{Introduction}

The Mhlathuze catchment supports a rapidly growing agricultural and industrial community in northern KwaZulu-Natal, South Africa (Steyl et al., 2000). $78.5 \%$ of the population dwelling in the catchment area are classified as rural. $63 \%$ of these people use dams, rivers and streams as their primary water sources. Sanitation services are unavailable for $34.8 \%$ of the population (Census, 1996).

With increasing demands on water resources and contamination from industrial waste and human activities, the potential outbreaks of water-borne diseases in this area continue to grow. In 1996, it was found that the bacteriological quality of the Mhlathuze River posed an increased risk of infectious disease transmission to the communities that were dependent on the river for household, recreation and other purposes (Department Of Water Affairs And Forestry (DWAF), 1996). According to the Institute of Water Quality Studies of DWAF (IWQS Report, 2000) this catchment area (W12 C-J) is high on the National Microbial Water Quality Monitoring Programme's priority list (14 ${ }^{\text {th }}$ in a total of 120$)$.

DWAF has adopted Strategic Environmental Assessment(SEA) as a tool in managing and planning the Mhlathuze catchment area by considering all aspects of the social, economic and biophysical

\footnotetext{
* To whom all correspondence should be addressed.

嘼 +2731 2044407; fax: +2731 2044809;

e-mail: jlin@pixie.udw.ac.za or lin2000j@yahoo.com

Received 12 May 2003; accepted in revised form 8 October 2003.
}

aspects of the environment (Steyl et al., 2000). The quality of water is typically determined by monitoring microbial presence, especially faecal coliform bacteria, and physico-chemical properties (Gray, 1994; DWAF, 1996; USA-EPA, 1999). However, the microbiological aspects of the water quality, namely the prevalence of human pathogens and indicator micro-organisms in the Mhlathuze catchment and surroundings have not been adequately addressed.

A previous study (1998 to 1999) showed high levels of faecal contamination in this area (Bezuidenhout et al., 2002). This problem is further compounded by the possible survival strategies of the viable but non-culturable state of bacterial flora in water systems (Colwell et al., 1985, Singh et al., 1986, Garcia-Lara et al., 1991). It is therefore imperative that microbial and physico-chemical data of the river are documented to provide comprehensive baseline information for future microbial monitoring purposes.

The primary aim of the study was to determine the microbial quality (total and faecal coliform counts) and some physicochemical parameters of the Mhlathuze River water source. Secondly the impact of environmental factors was compared with the previous results in the same area.

\section{Materials and methods}

\section{Sampling}

Five sites along the Mhlathuze River were selected for this study (Fig. 1). Site 1 (KwaDlangezwa) is situated near a sewage treatment plant at the University of Zululand. The area surrounding Site 2 


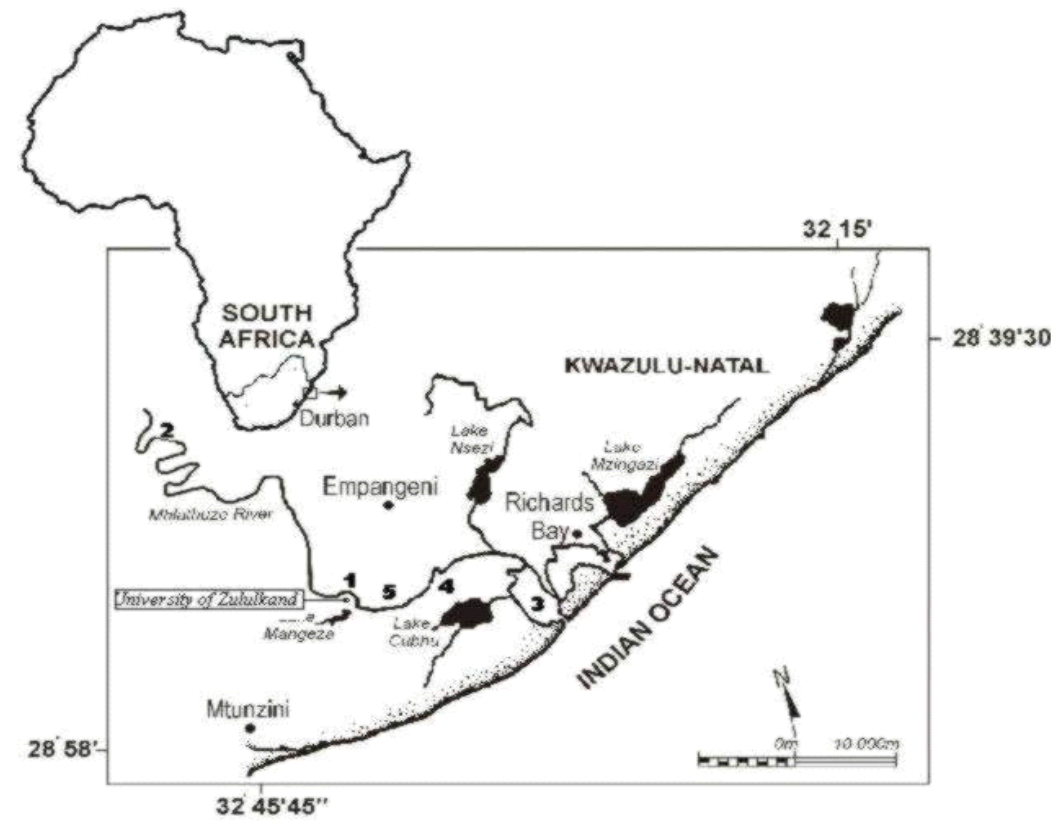

Figure 1

Map of the eastern region of the Mhlathuze Catchment area indicating the sampling sites (Site 1-KwaDlangezwa, Site 2-KwaDlangubo, Site 3-Mhlathuze Estuary, Site 4- Mhlathuze Pumping Station and Site 5- Felixton Bridge)
(Dlangubo) is mainly for agricultural developments such as sugar-cane. Site 3 is the Richards Bay estuary located near aluminum smelters and fertiliser manufacturing factories. Site 4 is the Mhlathuze pumping station, which has been expanded in 2001 to supply the water demands for new mining activities in the area. Site 5 (Felixton) hosts a sugar mill and paper-pulping factories as well as agricultural and informal farming activities.

All water samples were collected every two weeks in sterile Schott bottles between March 2001 and November 2002. Once collected, the samples were immediately stored on ice in a dark cooler box and transported to the laboratory. The samples were stored at $4^{\circ} \mathrm{C}$ and analysed within $6 \mathrm{~h}$ of collection.

\section{Physical and chemical analysis}

The chemical oxygen demand (COD), total nitrogen, nitrate, nitrite, ammonium, orthophosphate and total phosphate concentrations of each sample were analysed using Aqualytic AL282 as described by the manufacturer. The concentrations of heavy metals $\left(\mathrm{Pb}^{+2}, \mathrm{Cd}^{+2}, \mathrm{Cu}^{+2}, \mathrm{Al}^{+3}\right.$ and $\left.\mathrm{Hg}^{+2}\right)$ in water were measured using an atomic absorbance spectro-

TABLE 1

The geometric means of faecal coliform counts, physical and chemical characters measured in each site of the Mhlathuze River over the study period between February 2001 to November 2002

\begin{tabular}{|c|c|c|c|c|c|c|}
\hline Site & Site 1 & Site 2 & Site 3 & Site 4 & Site 5 & $\begin{array}{l}\text { Recommended } \\
\text { limit for no risk }\end{array}$ \\
\hline $\mathrm{T}\left({ }^{0} \mathrm{C}\right)$ & $15-31.6(23.3)$ & $17-30.85(25.2)$ & $16.5-31.2(25.9)$ & $18-29.4(24.2)$ & $15-30.7(23.2)$ & na \\
\hline $\mathrm{pH}$ & $5.8-8.3(7.6)$ & $5.93-8.47(7.74)$ & $5.94-8.19(7.51)$ & $6.9-8.58(7.73)$ & $6.83-8.38(7.70)$ & $5.0-9.0$ \\
\hline Turbidity (NTU) ${ }^{\mathrm{a}}$ & $0.8-9.0(5.63)$ & $2.5-7.6(6.1)$ & $2.1-20.2(7.56)$ & $2.3-17.8(13.4)$ & $1.4-33.0(7.80)$ & $<0.1$ \\
\hline Conductivity $\left(\mathrm{mS} . \mathrm{cm}^{-1}\right)^{a}$ & $350-696(480.9)$ & $218-524(391.9)$ & $1970-51800(25700)$ & $263-705$ (491.5) & $221-717(462.6)$ & $<700 \mathrm{mS} . \mathrm{cm}^{-1}$ \\
\hline $\mathrm{DO}\left(\mathrm{mg} \cdot \boldsymbol{\ell}^{-1}\right)^{\mathrm{a}}$ & $36.2-51.6$ & $33.3-51.0$ & $32.0-43.3$ & $32.0-41.9$ & $31.7-43$ & na \\
\hline Total N (mg $\left.\boldsymbol{\ell}^{-1}\right)^{b}$ & $1.6-5.6(2.41)$ & $0.5-5.9(1.43)$ & $1.4-2.4(1.67)$ & $1.5-8.5(3.33)$ & $1.3-7.7(2.78)$ & $<6$ \\
\hline $\mathrm{NO}_{2}^{-}\left(\mathrm{mg} \cdot \boldsymbol{\ell}^{-1}\right)^{\mathrm{b}}$ & $0.06-1.9(0.20)$ & $0.06-0.8(0.15)$ & $0.03-0.8(0.17)$ & $0.02-4.8(0.22)$ & $0.02-0.8(0.15)$ & na \\
\hline $\mathrm{NO}_{3}^{-}\left(\mathrm{mg} \cdot \boldsymbol{\ell}^{-1}\right)^{\mathrm{b}}$ & $0.3-1.0(0.59)$ & $0.5-0.7(0.59)$ & $0.2-0.6(0.33)$ & $0.3-0.9(0.62)$ & $0.2-1.1(0.48)$ & $<26$ \\
\hline $\mathrm{NH}_{4}^{+}\left(\mathrm{mg} \cdot \ell^{-1}\right)^{\mathrm{b}}$ & $0-0.23(0.06)$ & $0.01-0.06(0.03)$ & $0.03-0.24(0.07)$ & $0.02-0.34(0.08)$ & $0-0.13(0.04)$ & na \\
\hline Total $\mathrm{P}\left(\mathrm{mg}^{\cdot} \boldsymbol{\ell}^{-1}\right)^{\mathrm{b}}$ & $1.3-2.8(1.9)$ & $1.8-4.8(2.9)$ & $3.6-32.0(10.7)$ & $1.0-8.3(2.9)$ & $1.3-10(3.6)$ & $<1$ \\
\hline Ortho-P $\left(\mathrm{mg} \cdot \ell^{-1}\right)^{b}$ & $0.2-0.5(0.28)$ & $0.19-0.87(0.53)$ & $0.20-0.94(0.44)$ & $0.46-0.80(0.67)$ & $0.20-0.68(0.34)$ & na \\
\hline $\mathrm{Cd}^{+2}\left(\mathrm{mg} \cdot \boldsymbol{\ell}^{-1}\right)$ & nd & $0-0.001$ & $0-0.006$ & nd & $0-0.011$ & $<0.003$ \\
\hline $\mathrm{Cu}^{+2}\left(\mathrm{mg} \cdot \boldsymbol{\ell}^{-1}\right)$ & nd & $0.002-0.022$ & $0.039-0.11$ & nd & $0.004-0.047$ & $<1$ \\
\hline $\mathrm{Al}+3\left(\mathrm{mg} \cdot \boldsymbol{\ell}^{-1}\right)$ & nd & $10.9-12.7$ & $27.9-44.7$ & nd & $13.1-32.2$ & na \\
\hline $\mathrm{Hg}+2\left(\mathrm{mg} \cdot \boldsymbol{\ell}^{-1}\right)$ & nd & $0-1.19$ & $0.52-3.29$ & nd & $0-0.8$ & na \\
\hline $\mathrm{Pb}^{+2}\left(\mathrm{mg} \cdot \ell^{-1}\right)$ & nd & $0-0.001$ & $0.003-0.056$ & nd & $0.002-0.004$ & na \\
\hline $\mathrm{BOD}^{\mathrm{b}}$ & $0-1.35(0.21)$ & $0-0.90(0.23)$ & $0-1.00(0.41)$ & $0-1.2(0.48)$ & $0-0.80(0.24)$ & na \\
\hline $\operatorname{COD}\left(\mathrm{mg} \cdot \ell^{-1}\right)^{b}$ & $9-72.5(22.3)$ & $2.5-21.5(11.9)$ & $18.0-126.0(33.6)$ & $4.0-25.0(12.5)$ & $1.3-34.5(19.7)$ & na \\
\hline $\begin{array}{l}\text { Faecal Coliform count/ } \\
100 \mathrm{~m} \ell \text { (mean) }\end{array}$ & $10-900(292)$ & $20-2600(642)$ & $0-200(54)$ & $40-26800(1937)$ & $20-6120(1118)$ & 0 \\
\hline Ratio after resuscitation $* \mathrm{~b}$ & $1.5-23.3$ & $1.5-10$ & $1.25-4.0$ & $1.25-7.5$ & $1.3-2.5$ & \\
\hline \multicolumn{7}{|c|}{$\begin{array}{l}\text { * ratio of faecal coliform counts with or without resuscitation procedure. } \\
\text { a From October } 2001 \text { to present. } \\
\text { b From June } 2002\end{array}$} \\
\hline
\end{tabular}


meter. The temperature, $\mathrm{pH}$, conductivity, dissolved oxygen (DO) concentration and turbidity were monitored on site using Corning Checkmate II with portable thermometer, $\mathrm{pH}$, turbidity and DO meters and Aqualytic turbidity meter respectively. Biological oxygen demand (BOD) values were obtained based on the instructional manual of the Aqualytic Sensomat System. Rainfall data was kindly provided by the South African Weather Bureau.

\section{Microbiological analysis}

A series of ten-fold dilutions of the water samples were used for the enumeration of bacterial counts using plate count and membrane filtration (Millipore, HANG $47 \mathrm{~mm}$ ) methods. mEndo Les, $\mathrm{mFc}$ and S-S agars (Merck) were used to determine heterotrophic bacterial, total coliform, faecal coliform and Salmonella and Shigella spp. respectively. Plates were incubated at $35^{\circ} \mathrm{C}$ for $24 \mathrm{~h}$ with the exception of the $\mathrm{mFc}$ plates which were incubated at $44.5^{\circ} \mathrm{C}$ for $24 \mathrm{~h}$. Experiments were performed in duplicate.

\section{Resuscitation of VBNC bacteria}

Resuscitation was carried out using the DVC method of Kogure (1979). Nine thousand seven hundred and thirty $\mu \ell$ of sample was resuscitated using $20 \mu \ell(0.002 \%)$ nalidixic acid and $250 \mu \ell$ $(0.025 \%)$ yeast extract. The sample was then incubated in the dark on a shaker $\left(160 \mathrm{r} \cdot \mathrm{min}^{-1}\right)$ at room temperature for $6 \mathrm{~h}$. Bacterial enumeration after resuscitation was obtained using the membrane filtration method as described above and compared with the one without resuscitation.

\section{Statistical analysis}

Geometric means of microbiological and of physical and chemical analysis data were used to present monthly values. Pearson's product moment correlations were used to correlate faecal coliform counts to the water temperature and the rainfall figures.

\section{Results}

Table 1 shows the physico-chemical parameters and faecal coliform counts of the water samples collected from 5 different sites along the Mhlathuze River during the study period. Most of the physical and chemical values obtained were within South African guidelines (DWAF, DOH and WRC 1998; Table 1). During the rainy period, the turbidity of the Mhlathuze River beyond Felixton increased above the drinking water safety guideline which is less than 0.1 NTU. Water samples from Sites 4 and 5 , which contained higher concentrations of total nitrogen and phosphate, possessed higher faecal coliform contamination. Resuscitation of water samples increased total and faecal coliforms up to 65 and 23 folds respectively. Due to the high salt concentration at the Richards Bay Estuary, the bacterial counts were much lower than those at other sites. High concentrations of metals (Table 1) were detected in the water samples from Felixton and estuary.

Figure 2 shows the geometric values of the total coliform counts from all five sites during this study period as well as the data from our pervious study (Bezuidenhout et al., 2002). The results showed that the total coliform counts of the Mhlathuze River in this study period were significantly higher than those reported by Bezuidenhout et al. (2002). During 2001 the total coliform population in the Mhlathuze River showed larger fluctuations than in other years. These fluctuations were not observed in 2002. The water temperature followed a typical summer and
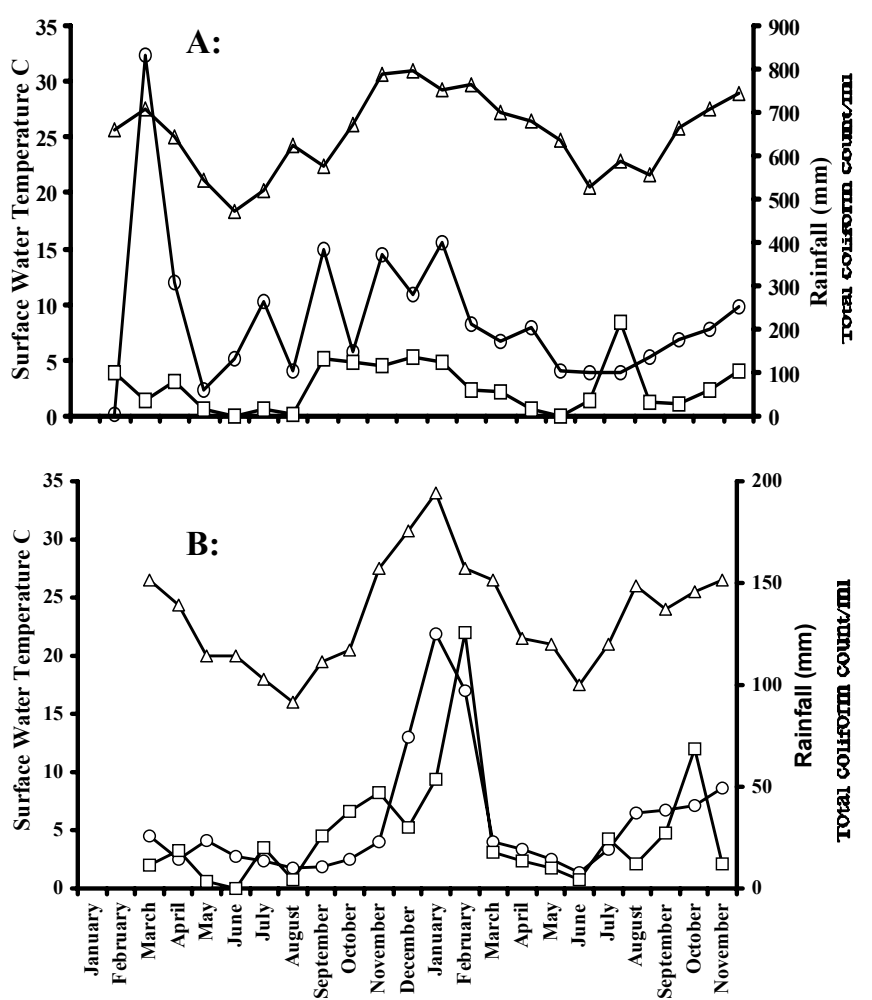

Figure 2

The monthly mean of total coliform counts, rainfall figures and temperature in all of the five sites along the Mhlathuze River. A) February 2001 - November 2002 period; B) March 1998November 1999 period. (Bezuidenhout et al, 2002).

Key: O: Total coliform count; $\triangle$ : water surface temperature; $\square$ : Rainfall figures.

winter trend. However, the average water temperatures during the summer period were higher than those during 1998 to 1999 with the exception of the temperatures recorded during January 2002 which was averaged at $34^{\circ} \mathrm{C}$ (Fig. 2). The rainfall figures were also higher in the same period than those in the previous study with the exception of that during February 2002. Pearson's correlation coefficient (r) analysis showed weaker correlations between the faecal coliform counts to the water temperature $(r=0.48)$ and to the rainfall figures $(r=0.31)$, compared to the previous study.

The trends in the total and the faecal coliform counts for the same period were similar. Despite the increases in total coliform counts of the water system, the level of faecal coliform counts did not change compared to those observed in the previous study (Fig. 3) with the exception of a wider fluctuation during 2001. Felixton (Site 5) continued to be the main site of faecal contamination as observed during the 1998 and 1999 period. There was a sudden peak of faecal coliform counts during November and December of 2001. This sudden increase in faecal coliform count was mainly due to the faecal contamination at the Mhlathuze pumping station (Fig. 4). Although the Mhlathuze pumping station also proved to be the main site of faecal contamination during 2001, the situation improved during 2002.

A comparison of the trends in the faecal coliform counts at each site along the Mhlathuze River during this study period showed no obvious seasonal changes as suggested in the previous study (Fig. 5). The present findings may be due to the pattern of 


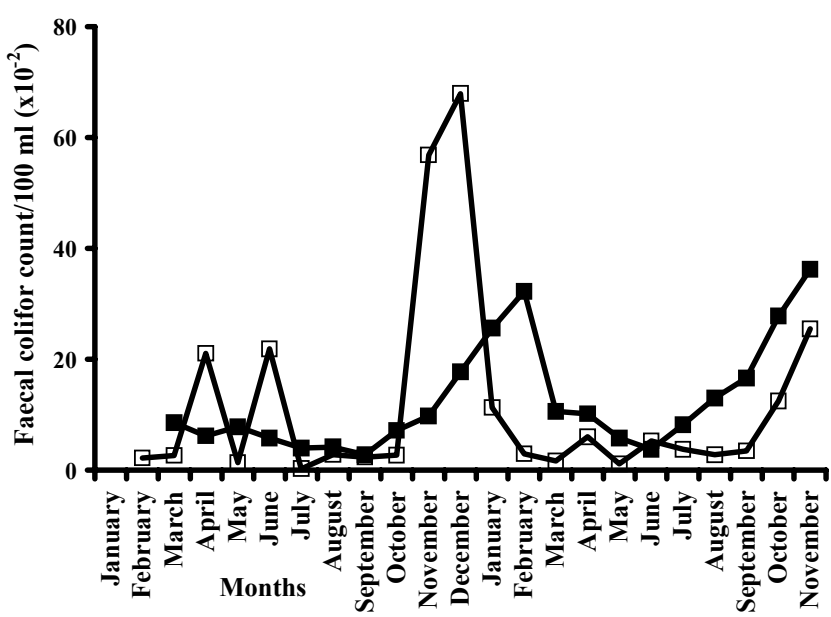

Figure 3

The monthly mean of faecal coliform counts at all five sites along the Mhlathuze River during two study periods.

ㅁ: Faecal coliform counts for February 2001- November 2002;

口: Faecal coliform counts for March 1998- November 1999).

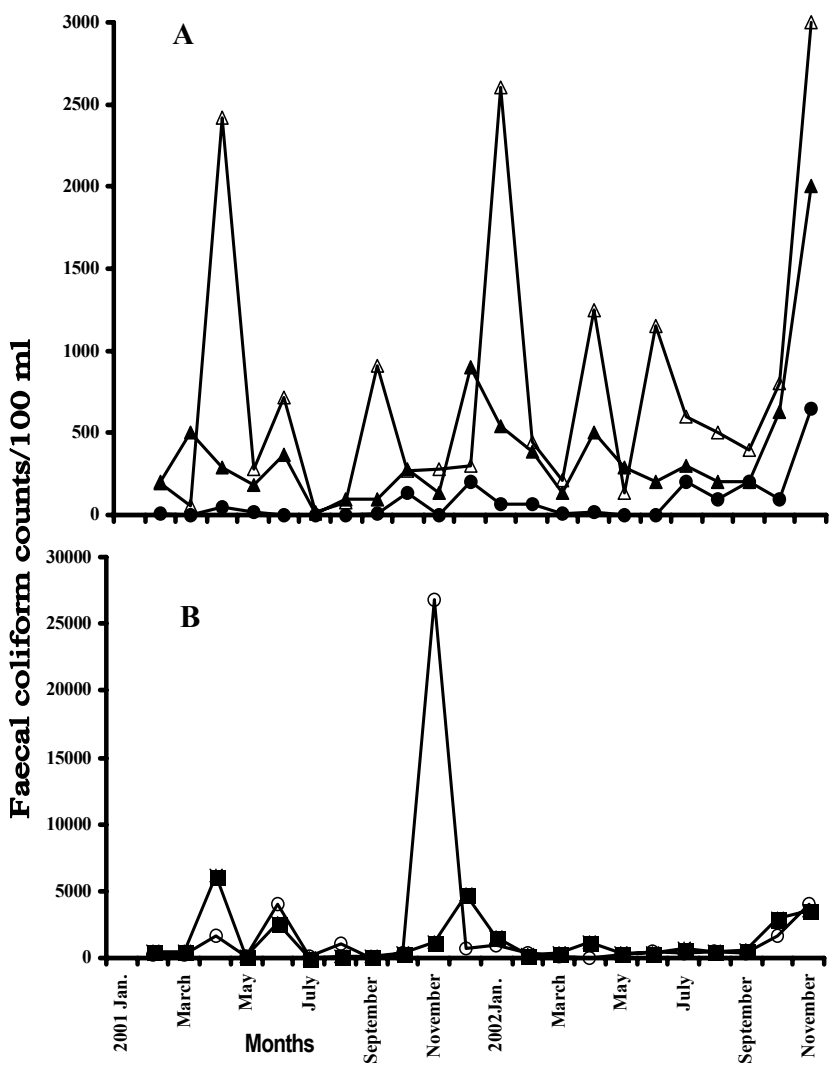

Figure 4

The monthly mean of faecal coliform counts at each site along the Mhlathuze River during the study period (February 2001November 2002). (A: $\square$ :Kwa Dlangezwa Site 1;

$\triangle K$ waDlangubo Site 2; • Richard Bay Estuary Site 3; B:

O Mhlathuze Pumping Station Site 4; $\mathbf{\square}$ : Felixton Site 5)

fluctuation in 2001. With the exception of some sudden increases of faecal coliform counts at Sites 4 and 5 during 2001, the faecal contamination in the Mhlathuze River generally was low during this study period.

\section{Discussion}

The Mhlathuze catchment supports a rapidly growing agricultural and industrial community. It also serves most of the domestic needs of the large rural population which resides in this region (Steyl et al., 2000). This coastal area has significant economic potential and provides employment opportunities for people from the area, as well as individuals from more remote areas. With increasing demands on water resources and contamination from industrial waste and human activities, the potential outbreaks of water-borne diseases continue to grow (DWAF, 1996).

The results of our previous study of the Mhlathuze River (Bezuidenhout et al., 2002) demonstrated seasonal patterns for the bacteriological counts for the period March 1998 to November 1999. Strong correlation was demonstrated between bacterial counts and rainfall figures as well as water surface temperatures. The seasonal patterns of microbial growth prevailed during the current study (Figs. 2 to 5) and are strongly supported by other studies (Byamukama et al., 2000; Lobitz et al., 2000; Nishiguchi, 2000; Solo-Gabrielle, 2000; Nübel et al., 1999). The mean surface water temperature (constantly between $20-34^{\circ} \mathrm{C}$ ) of the Mhlathuze River during the summer period is ideal for the prolonged survival of coliform bacteria. Pearson's correlation coefficient ratios between the temperature and rainfall figures to the bacterial counts were not significant during 2001 to 2002 as were the values for 1998 to 1999 . However, the fluctuation patterns of total and faecal coliform counts may have affected the reliability of the analysis.

There were significant increases in total coliform counts in the present study compared to those observed in the previous study (Fig. 2). The fluctuation patterns for the total coliform and faecal coliform counts were also observed during 2001 (Figs. 2 and 3). Despite the substantial increase in the total coliform counts, the degree of faecal contamination during the same period remained similar to that in 1998.

The Mhlathuze pumping station (Site 4) and Felixton (Site 5) were the main contributors to the sudden increases of total coliform counts and the observed fluctuation pattern (Figs. 4 and 5). This phenomenon coincided with the construction of the Mhlathuze pumping station. The normalisation of the levels of contamination coincided with the completion of the construction of the pumping station at the end of 2002.

Felixton continues to be the main site of faecal contamination as observed in the previous study (Fig. 4). Lower faecal coliform counts were in fact observed at Sites 1 and 3 during this study period (Fig. 5). All environmental factors as reported in the previous study (Bezuidenhout et al., 2002) especially human activities, affecting the microbial quality of the water system prevailed since 1998

Most of the physico-chemical parameters detected in this study (Table 1) were within the acceptable ranges of water quality for the domestic supply (DWAF, DOH and WRC, 1998). The turbidity of the Mhlathuze River was generally higher during the summer period and increased up to $33.0 \mathrm{NTU}$ which may have serious consequences if consumed (DWAF, DOH and WRC, 1998). Generally, higher geometric means of the chemical values at the Mhlathuze pumping station (Site 4) coincided with the higher total coliform counts at the same site during the study period. High concentrations of cadmium $\left(0.011 \mathrm{mg} \cdot \boldsymbol{\ell}^{-1}\right)$ and lead $\left(0.056 \mathrm{mg} \cdot \ell^{-1}\right)$ were detected at Felixton and Richards Bay Estuary. DWAF, DOH and WRC (1998) reported that the concentration of cadmium in the range of 0.005 to $0.02 \mathrm{mg} \cdot \ell^{-1}$ might have health implications in sensitive groups. The higher aluminum concentrations at the Richards Bay estuary and Felixton were most probably due to the 

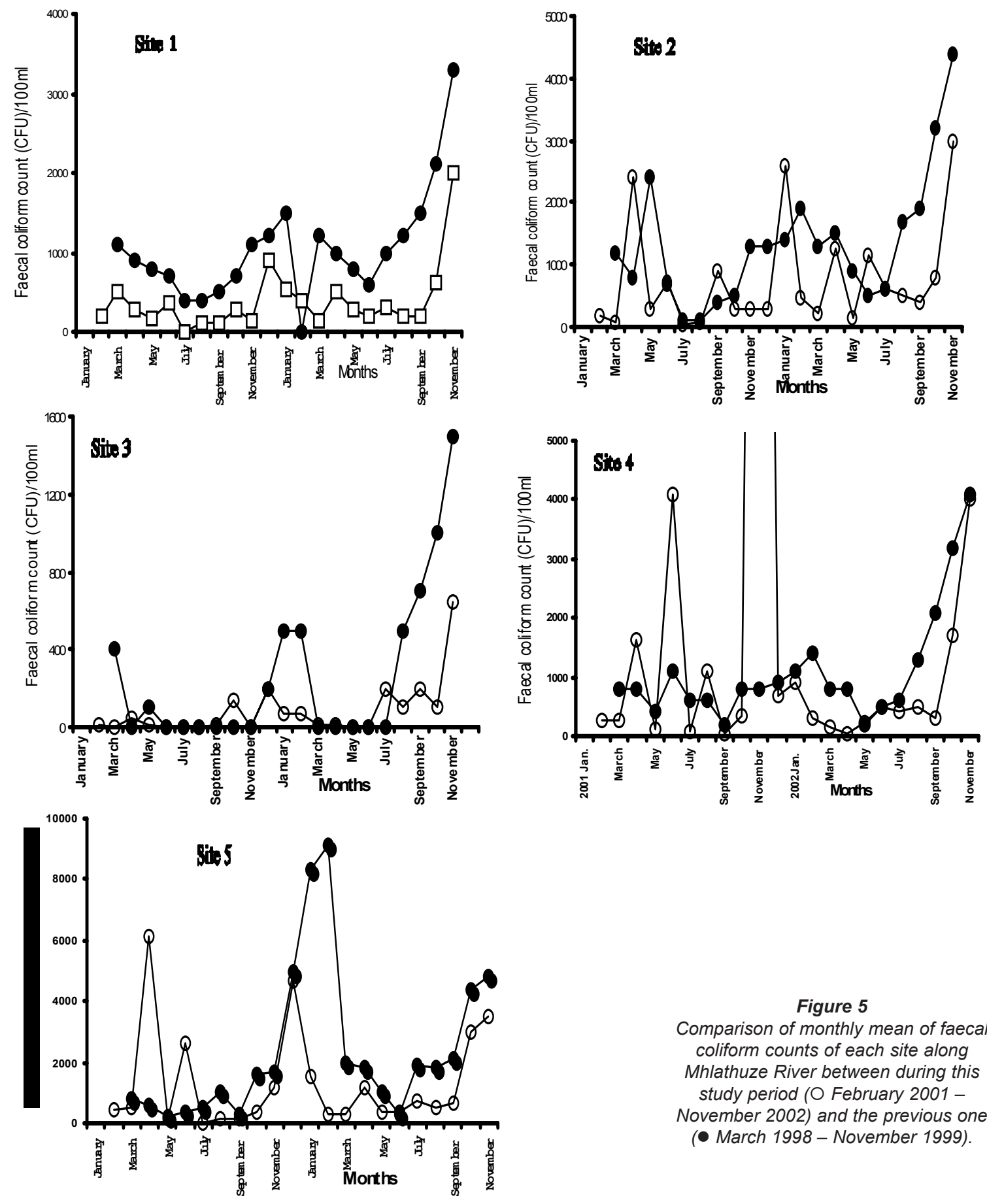

Figure 5

Comparison of monthly mean of faecal coliform counts of each site along Mhlathuze River between during this study period (O February 2001 November 2002) and the previous one (• March 1998 - November 1999).

nearby aluminum smelters. It would be interesting to investigate the prevalence of clinical cases linked to the presence of the heavy metal in this area.

The "viable but non-culturable" (VBNC) state, an important survival strategy of several pathogenic micro-organisms such as Salmonella, Shigella and Vibrio spp. has caused increasing public health concerns. After resuscitation, the faecal coliform counts of the water samples increased up to 23 times in this study (Table 1). The results suggest that the level of faecal contamination in the Mhlathuze catchment should be of concern. Therefore the real impact of this VBNC state in this water system should be investigated.

\section{Conclusion}

The results from the various focus areas of this study show that, although contamination of the river is generally constant over time, there are periods when very large increases in bacterial numbers occur. The following factors influenced the observed elevated levels of total and faecal coliform bacteria:

- Activities (domestic, recreational, agricultural, and industrial) along the river increase during the summer period. At Felixton, for example, a sugar-mill and a paper factory are operating at full capacity and informal agricultural activities continue to increase. The construction at the Mhlathuze pumping station 
during the 2001 period caused severe fluctuations in bacterial growth.

- The catchment is situated in a summer rainfall area and increased runoff is thus expected in the summer period annually.

- Surface water temperatures of between $20^{\circ} \mathrm{C}$ and $31^{\circ} \mathrm{C}$ were regularly detected during the summer period.

Evidence from our results suggests that more attention should be given to the impact of VBNC state of pathogens in the environment.

\section{Acknowledgment}

The project leader wishes to thank the National Research Foundation (GUN 2038429) and the Water Research Commission (K5/ 1282) for the financial support of this study. We would also like to thank the South African Weather Bureau for the rainfall figures and the Mhlathuze Water Board for the determinations of metal concentrations in our water samples.

\section{References}

BEZUIDENHOUT C, MTHEMBU N, PUCKREE T and LIN J (2002) Microbiological evaluation of the Mhlathuze River, KwaZulu-Natal (RSA). Water SA 28 (3) 281-286.

BYAMUKAMA D, KNASIIME F, MACH RL and FARNLEITNER H (2000) Determination of Escherichia coli contamination with chromocult coliform agar showed a high level of discrimination efficiency for differing fecal pollution levels in tropical waters of Kampala, Uganda. Appl. Environ.Microbiol. 66 (2) 864-868.

CENSUS (1996) http://www.statssa.gov.za/ uMhlathuze Region.

COLWELL RR, BRAYTON PR, GRIMES DJ, ROSZAK DB, HUQ SA and PALMER LM (1985) Viable but non-culturable Vibrio cholerae and Related pathogens in the environment: implications of release of genetically engineered micro-organisms. Biotechnol. 3 817-820.

DEPARTMENT OF WATER AFFAIRS AND FORESTRY (DWAF) (1996) South African Water Quality Guidelines, Domestic Water Use ( $2^{\text {nd }}$ edn.), Pretoria. 77-99.

DEPARTMENT OF WATER AFFAIRS AND FORESTRY (DWAF), DEPARTMENT OF HEALTH (DOH) AND WATER RESEARCH COMMISSION (WRC) (1998) Quality of Domestic Water Supplies. Vol. 1: Assessment Guide.
GARCIA-LARA J, MENON P, SERVAIS P and BILLEN G (1991) Mortality of faecal bacteria in seawater. Appl. Environ. Microbiol. 57 885-888.

GOÑI-URRIZA M, CAPDEPUY M, ARPIN C, RAYMOND N, CAUMETTE P and QUENTIN C (2000) Impact of an urban effluent on antibiotic resistance of riverine Enterobacteriaceae and Aeromonas spp. Appl. Environ. Microbiol. 66 (1) 125-132.

GRAY NF (1994) Drinking Water Quality, Problems and Solutions. John Wiley and Sons Ltd, England.

INSTITUTE FOR WATER QUALITY STUDIES (IWQS), 2000, A First Report On the Identification and Prioritization of Areas in South Africa With a Potentially High Health Risk Due to Faecally Polluted Surface Water. Report No N /0000/00/RE/Q/4399; DWAF, Pretoria.

KOGURE K, SIMIDU U and TAGA N (1979) A tentative direct microscopic method for counting living marine bacteria. Can. J. Microbiol. 25 415-420.

LOBITZ B, BECK L, HUQ A, WOOD B, FUCH G, FARUQUE ASG and COLWELL R (2000) Climate and infectious disease: Use of remote sensing for detection of Vibrio cholerae by indirect measurement. Proc. Natl. Acad. of Sci.USA. 97 (4) 1438-1443.

NISHIGUCHI MK (2000) Temperature affect species distribution in symbiotic populations of Vibrio spp. Appl. Environ. Microbiol. 66 (8) 3550-3555.

NÜBEL U, GARCIA-PICHEL F, KUHL M and MUYZER G (1999) Quantify microbial diversity: Morphotypes,16S rRNA genes and caretenoids of organic phototropes in microbial mats. Appl. Environ. Microbiol. 65 (2) 422-430.

PRETORIUS L (2000) An investigation into the effect of various levels of sanitation on surface water quality in a typical developing community. SA Water Bulletin 26 (3) 10-12.

SINGH A, YEAGER R and McFETERS GA (1986) Assessment of in vitro revival, growth and pathogenicity of Escherichia coli strains after copper and chlorine induced injury. Appl. Environ. Microbiol. 52 832-837.

SOLO-GABRIELEHM, WOLFERT MA, DESMARAIS TR and PALMER CJ (2000) Sources of Escherichia coli in a coastal subtropical environment. Appl. Environ. Microbiol. 66 (1) 230-237.

STEYL I, VERSFELD DB and NELSON PJ (2000) Strategic Environmental Assessment for Water Use: Mhlathuze Catchment KZN. DWAF Report No SEA-01/2000.

USA ENVIRONMENTAL PROTECTION AGENCY (EPA) (1999) 25 Years of the Safe Drinking Water Act: History and Trends 816-R-99007. 